\title{
FRANCHISEES' LEVEL OF SATISFACTION WITH THE FRANCHISE RELATIONSHIP
}

\author{
Gerhard J. van Wyk Faculty of Management Sciences, Tshwane University of Technology, \\ Johan W. de Jager, Faculty of Management Sciences, Tshwane University of Technology,
}

\begin{abstract}
Problem investigated and objectives: Franchisees often complain that franchisors do not meet their needs, and are generally viewed as being unhappy with the franchise relationship between franchisees and franchisors. The aim of this paper is to investigate the level of satisfaction of franchisees with the franchise relationship, including the following elements: franchisee independence, support with the selection of a distribution point, allocation of geographical trading areas, support with the design and layout of distribution points, comprehensive training programmes, the provision of continuous market and product information and operational support, and advertising and financial support, including systems for bookkeeping.
\end{abstract}

Approach: The data represents two groups of the same franchise, namely franchisees operating for two years and less as franchisees and franchisees who have been operating for longer than two years as franchisees. The extent to which these two groups view the relationship elements differently will be examined.

Findings: The findings indicate that both groups had a high level of satisfaction with the franchise relationship between franchisees and franchisors, with the exception of identified opportunities, which could be further developed in order to increase the franchisees' level of satisfaction with the franchise relationship between franchisees and franchisors.

Conclusion: In view of the results of this research, it was concluded that the franchisees of the selected franchisor in the franchise industry displayed a high level of satisfaction with the franchise relationship between franchisors and franchisees.

Keywords: Franchisees' satisfaction, franchisee and franchisor, franchise relationships, marketing orientation, Franchise Association of Southern Africa (FASA), franchise agreement, franchise legislation.

\section{INTRODUCTION}

Franchised companies in South Africa are often dissatisfied with the franchise relationship because they believe they do not get the necessary support from franchisors. Terblanche and Smit (1994) point out that some of the local and international franchise systems do not deliver on promises made to franchisees. According to Ueckerman (2003), the large corporate companies in South Africa have little interest in franchises. As a result, the support for franchise systems is largely based with medium to small companies with limited resources. In many instances, franchise concepts are being sold by franchisors without them being properly researched and tested. In South Africa, anyone with a good concept could start trading as a franchise, with the result that franchise concepts do not always meet franchisees' needs. This often results in an unhappy franchise relationship between franchisees and franchisors (Ueckerman, 2006).

Berger (2007) points out that most franchisors underestimate the support franchisees will demand from them, which results in their actions not being marketing-orientated. According to research conducted by Slater and Naver (1994), marketing-orientated companies are better placed to identify and capitalise on new opportunities than non-marketing-orientated companies. The aim of the paper is to assist franchisors in determining franchisees' needs and level of satisfaction with regard to the franchise relationship.

\section{FRANCHISE RELATIONSHIPS}

Spinelli, Rosenberg and Birley (2004) confirm that the franchise relationship between franchisees and franchisors starts with the needs of consumers and businesses' attempt to meet those needs through cooperation between franchisees and franchisors. Both franchisors and franchisees have specific expectations of each other in the franchise relationship (Shiveill \& Banning, 1995). Franchising is a process of mutual trust based on transparent relationships between franchisees and franchisors (Calitz, 2002). Mutual trust between people is the cornerstone of any business relationship (Svensson, 2004). 
St Jacques and St Jacques (2006) argue that franchisees and franchisors are inter-dependent on one another and that one is not more important than the other in the franchise relationship. Both franchisors and franchisees are linked to the success of a franchise, as franchisees invest capital in the franchise while the franchisor's trade name and business concept are at risk (Abatzoglou, 2002). The ingredient that distinguishes franchising from most other forms of business activities is the symbiotic relationship of interdependence that exists between legally distinct economic entities (Krige, 2001). The franchise relationship between franchisees and franchisors in South Africa is managed by means of a contract between franchisors and franchisees (Gordon, 2002).

\section{Franchisees' expectations of the franchise relationship}

Franchisees often have the following expectations of franchisors in the franchise relationship: a high level of independence, support with the selection of a distribution point, support with the selection and design of a distribution point, high levels of potential revenue, training programmes, market and product information, operational support, advertising and promotional support, support to obtain finance, and systems for bookkeeping.

Shivell and Banning (1995) point out that franchisees usually expect a high level of independence when joining a franchise, but soon discover that the opposite is the case, as a high level of control by the franchisor exists in successful franchise systems. Franchisees expect franchisors to assist with the selection of distribution points, backed by feasibility studies and research conducted by the franchisor (Shivell \& Banning, 1995) and (Luhn, 1994). Franchisees expect that exclusive geographical rights as allocated by franchisors and protected by the franchise agreement will not allow the franchisor to appoint any other franchisee to a specific geographical area already allocated for the duration of the original contract period (Shivell \& Banning, 1995). Terblanche and Smit (1994) argue that franchisees firstly buy into franchise concepts based on the potential financial rewards of an existing, tested and formulated business system as provided by the franchisor, followed by factors such as a lower business risk and the recovery rate of invested capital.

Franchisees expect franchise packages to include a proven and tested franchise system and agreement, an operational manual, a disclosure document and particulars of the training to be provided by the franchisor (Swart, 2002; Macqueen, 2006). Franchisors need to provide franchisees with the relevant training that will allow franchisees to be as successful as possible (Luhn, 1994). Franchisees insist on these services and support by franchisors, and are of the opinion that they pay for these service by means of the monthly franchise fees payable to franchisors (Shivell \& Banning, 1995). Osso (2004) points out that franchisors provide supporting packages and services, including initial and ongoing training, the management of promotional campaigns, operational manuals, continuous communication, marketing and administrative support, market research and product support. Franchisors are responsible for the management of the advertising budget and the promotion of trade names, as franchisees contribute to an integrated marketing communication plan (Raphaële \& Rafter, 1998). Franchisors are expected to assist franchisees in obtaining finance or even to provide franchisees with financial support (Luhn, 1994).

\section{Franchisors' expectations of the franchise relationship}

Franchisors, just like franchisees, have specific expectations of the franchise relationship. These expectations include the continuous use and promotion of products and services of the franchisors by the franchisees, adherence to quality and operational standards, and the promotion of sales. Calitz (2002) and Weaven and Frazer (2006) argue that tested trade names and business systems as provided by franchisors contribute to the success of franchisees. Franchisors expect franchisees to support and promote the trade names and products provided by franchisors in order to guarantee the continued existence of the trade name (Shivell \& Banning, 1995). Charney (1996) and Osso (2002) confirm that franchisors demand that franchisees meet the quality standards contained in the operational manual. Franchisees are responsible for the promotion and development of continuous sales, based on predetermined standards provided by the franchisor (Raphaële \& Rafter, 1998). Franchisors demand that franchisees follow the standardised programmes and procedures prescribed by the franchisor in the operational manual. Operational manuals need to be comprehensive documents detailing the processes to be followed by franchisors (Charney, 1996; Osso, 2002). 


\section{THE RELATIONSHIP BETWEEN FRANCHISEES AND FRANCHISORS DURING THE FRANCHISE LIFECYCLE}

The term "relationship" refers to the way in which two or more people or things are connected, or the state of being connected (Krige, 2001). Thus, relationships are complex and bound to evolve over time. The term "lifecycle" refers to a series of events that are regularly repeated in the same order in the period between life and death (Krige, 2001). Franchise concepts and franchises, like other types of organisations, go through different lifecycle phases that have a positive or negative effect on the franchise relationship between franchisees and franchisors. Nieman (1998) confirms the existence of the following lifestyle phases that could lead to conflict between franchisors and franchisees: the introduction phase, the growth phase, the mature phase and the decline phase or redevelopment phase. Parker and Osso (2000) support Nieman (1998) and indicate, as shown in Table 1, franchisees' level of satisfaction in the different stages of the franchise lifecycle.

Table 1: Franchisees life cycle process

\begin{tabular}{|c|c|c|c|c|}
\hline $\begin{array}{l}\text { Introduction } \\
\text { Phase } 1\end{array}$ & $\begin{array}{l}\text { Growth - "We" } \\
\text { Phase } 2\end{array}$ & $\begin{array}{l}\text { Mature - "Me" } \\
\text { Phase } 3\end{array}$ & $\begin{array}{l}\text { Declining } \\
\text { "Rebel" Phase } 4\end{array}$ & $\begin{array}{l}\text { Start of a new cycle } \\
\text { or Phase } 1\end{array}$ \\
\hline \multicolumn{2}{|c|}{$1-2$ years } & \multicolumn{2}{|c|}{2 years and longer } & Contract renewal \\
\hline $\begin{array}{ll}\mathrm{FSI} & 90 \%\end{array}$ & $78 \%$ & $70 \%$ & FSI $56 \%$ & $90 \%$ \\
\hline
\end{tabular}

\section{Source: Adapted from Parker and Osso (2000) and Krige (2001).}

Krige (2001) reports a correlation within the domain of the management of the franchisor/franchisee relationship, which shows strong deteriorating levels of franchisee satisfaction and relationship quality as the franchisee progresses through the four lifecycle phases, also known as the courting phase, the "we" phase, the "me" phase and the rebel phase.

\section{Introduction phase}

Franchisees depend heavily on franchisors in the introduction phase, as they often have little experience and need a lot of start-up support from the franchisor (Franchise Digest, 1999). Morgan, Hunt and Nathan (2003) agree with the Franchise Digest (1999) and point out that the franchisees in the introduction phase are very happy with the franchise relationship. According to Table $1,90 \%$ of new franchisees prefer to continue with the relationship. The highest levels of franchisee commitment, trust, satisfaction and relationship quality are recorded in this phase (Krige, 2001). Nathan (2006) states that the positive relationship between franchisors and franchisees in the introduction phase could last for between three and twelve months. Conflict in the relationship between franchisors and franchisees is often the result of bad selection processes during the introduction phase that could continue for the duration of the existence of the franchise (Frazer, 1998).

\section{Growth phase}

After signing the franchise agreement, the growth phase starts with the selection of the distribution point. The growth phase is also a period for the transfer of skills and for training provided by the franchisor to the franchisee. Franchisees are interested and hungry to learn from franchisors. The growth phase is also known as the "we" phase. Confidence in the franchisor is lower than in the introduction phase, with only $78 \%$ of franchisees preferring to continue with the franchise relationship (Morgan et al., 2003). Osso (2004) confirms that the expectation of the payment of continuous franchise fees by the franchisees to franchisors results in conflict between franchisees and franchisors. Conflict in the franchise relationship between franchisees and franchisors could also be related to the unfair escalation of franchise fees by the franchisor to the detriment of franchisees (Shivell \& Banning, 1995). Franchise fees are normally stipulated in the franchise contract, but if not accurately and properly managed, this aspect could lead to conflict between franchisors and franchisees in the franchise relationship. During this phase, the franchisees will still value the co- 
operative relationship with the franchisor and will work hard to make the most of the business relationship. It is however evident that the franchisee satisfaction already deteriorates, due to possible doubts, relationship conflict and restrictions enforced, among others (Krige, 2001).

\section{Mature phase}

According to Nathan (2006), the mature phase is also referred to as the "free" stage. Franchisees in this stage of the franchise life cycle are more familiar with the franchise processes and tend to use their own initiative instead of following the processes and procedures prescribed in the franchise agreement and franchisors' operational manual. This leads to conflict between franchisees and franchisors. Krige (2001) points out that in this phase, franchisees start questioning the need for royalty payments and generally regard the success achieved up to that stage as purely the result of their own hard work. Franchisees and franchisors in the mature phase understand what to expect from each other. The franchise satisfaction index for the mature phase is $70 \%$. The franchise relationship between franchisors and franchisees in this phase is described as: "You do your bit and we do ours" (Franchise Digest, 1999). Nathan (2006) points out that the franchise relation between franchisees and franchisors could deteriorate or prosper in this phase. The profitability of a franchisee and a positive attitude of franchisors towards their franchisees could assist in relieving conflict between franchisees and franchisors in the mature phase (Holmes, 2006).

\section{Decline phase}

During the decline phase, the relationship between franchisees and franchisors could deteriorate or strengthen into a more effective relationship. If the relationship deteriorates, it is often because of a drive for independence on the side of the franchisee as well as a weakening of communication between the franchisor and franchisees. The Franchise Digest (1999) argues that new life could be instilled in the franchise relationship during this phase if franchisors decide to buy back portions of the franchise from franchisees or decide to split the geographical area of a franchisee in the decline phase so that it is shared with a franchisee in the growth phase. The franchise satisfaction index in Table 1 for this phase is $56 \%$. According to Illetschko (2001), franchisees and franchisors in the decline phase have opposite expectations of the franchise relationship. Morgan et al. (2003) point out that approximately $5 \%$ of franchisors terminates their franchise relationship with franchisors in the decline phase. Most franchisees who made it for four years prepare for contract renewal in the fifth year, when the courtship of contract renewal will again take the relationship back to phase 1 of the Franchise lifecycle (Krige, 2001). Franchisors could use several methods to influence the franchise relationship between franchisees and franchisors positively during the declining phase.

\section{THE ROLE OF THE FRANCHISE ASSOCIATION OF SOUTHERN AFRICA}

The Franchise Association of Southern Africa (FASA) is a trade association for franchisors, franchisees and professional organisations that services the needs of the franchise sector. Its aim is to safeguard ethics in franchising and constantly advance the development of the concept for the benefit of all involved (Illetschko, 2005). The main objective of FASA is to provide guidelines and support for the franchise industry and to continue to play a critical role as mediator between franchisors and franchisees in the franchise relationship (Shivell \& Banning, 1995). Franchisees see FASA's primary role as that of a provider of information on franchising, an accreditation body and a watchdog body for the franchise sector (Parker \& Illetschko, 2007). FASA also represents franchising on government level, leads BEE initiatives, and provides and upholds the criteria for FASA membership. The relationship between franchisors and franchisees is very important for the success of any franchise; these relationships should be based on mutual respect, regular research, the development of new products and promotional campaigns (FASA, 2000). Friedman (2006) and Nelson (2006) argue the importance of the existence of a conflict management mechanism in order for franchisors to resolve conflict in the franchise relationship. Franchisors have a responsibility to select the right franchisee but also to develop a successful franchise based on a successful franchise relationship between franchisees and franchisors. 


\section{OBJECTIVES OF THE STUDY}

Franchised companies in South Africa are often dissatisfied with the franchise relationship because they believe franchisors do not meet their needs and do not provide franchisees with adequate support. The question is whether this is also the case with franchisees of a selected franchisor in the optometric industry. What is the level of franchisees' satisfaction with the franchise relationship between the selected franchisees and the franchisor?

The primary objective of the study is to determine the levels of satisfaction of franchisees of a selected franchise in the optometric industry with the franchise relationship between them and the franchisor. In the larger study the following secondary objectives were established: (1) to determine the needs of the selected franchisees with regard to the products and services prescribed and provided by the franchisor, (2) to determine the needs of the selected franchisees with regard to the prices and promotions prescribed and provided by the franchisor, (3) to determine the needs of the selected franchisees with regard to the distribution methods prescribed and used by the franchisor, and (4) to determine the needs of the selected franchisees with regards to staff and processes as prescribed and provided by the franchisor. For the purpose of this study, selected variables from all categories are dealt with.

\section{RESEARCH METHODOLOGY}

\section{Research hypotheses}

With regard to the objectives, the following hypotheses were formulated:

$\mathrm{Ho}_{1}$ - No significant differences exist between franchisees operating as franchisees for two years and less and franchisees operating for two years and longer as franchisees regarding their level of satisfaction with the franchise relationship.

$\mathrm{Ha}_{1}$ - Significant differences exist between franchisees operating for two years and less as franchisees and franchisees operating for two years and longer as franchisees regarding their level of satisfaction with the franchise relationship.

\section{The sample framework}

Research was conducted among franchisees of a selected franchise in the optometric industry in South Africa. the addresses of 145 distribution points of the selected franchise that are available on the Internet were used. A census survey was conducted and data was collected by means of selfadministered questionnaires, consisting of multiple-choice answers and scaled questions that were posted to respondents (franchisees). The questions relating to expectations and satisfaction levels in the questionnaire were developed from a literature review. The questionnaire for this research was designed in accordance with McDaniel and Gates' (2005) guidelines for the design of effective questionnaires. Validity refers to the extent to which a test measures what we actually wish to measure (McDaniel \& Gates, 2001; Zikmund, 2003). The research questionnaire was validated by means of pre-testing. Personal interviews were conducted with two respondents (who were excluded from the official survey), and notes were made regarding problematic questions and areas that needed to be corrected. Selected questions were omitted and others added in order to validate the content of the questionnaire. Before posting the questionnaires to the selected franchisees, care was taken to ensure that those franchisees were registered members of the selected franchise and that the postal information was correct. The respondents (franchisees) who provided data for the research all complied with the criteria for the study. The questionnaire consisted of the following sections: (1) demographics, (2) products and services, (3) prices and promotions, (4) distribution, and (5) staff and processes. Respondents were requested to arrange their levels of agreement in relation to 141 prestated variables on a 5-point Likert scale (ranging from 'strongly disagree' to 'strongly agree'). Of the 145 questionnaires that were posted to franchisees, 77 (53\%) were received back. Of these, 75 $(51,7 \%)$ could be used while two $(1,3 \%)$ were rejected because they were incomplete. 
In this study the SPSS (5) statistical package was used for the processing of raw tabulated data as part of the statistical analysis process. The means were used to measure the central tendency in this study. Malhotra (1996) states that the Cronbach's Alpha (coefficient alpha) is the average of all possible split-half coefficients resulting from different ways of splitting the scale items. The Cronbach`s Alpha value can vary from "0" to "1", with values below 0,6 indicating unsatisfactory internal consistency reliability The higher the coefficient, the higher the reliability of the instrument (a coefficient of 1,00 therefore being perfectly reliable). In order to ensure reliability and the level of internal consistence of the 141 (variables) that were contained in the questionnaire, the following Cronbach-alpha coefficients per consolidated section were obtained: Section A products and services - Cronbach-alfa 0,785, Section B prices and promotions - Cronbach-alfa 0,798, Section C distribution - Cronbach-alfa 0,685 and Section D staff and processes - Cronbach-alfa 0,679. This indicates an expectable level of internal consistency and the reliability of the measurement instrument that was used in this study compared to the statistical benchmarks of 0.7 given in the literature. Gay and Diehl (1992) state that a researcher can be very satisfied with reliability levels in the 0,80 s and levels in the 0,07s can also be accepted. Krige (2001) recorded Cronbach Alpha coefficients ranging from 0,735 to 0,906 in a similar study also relating to the franchisee-franchisor relationship.

The results of the survey conducted among franchisees of a franchise in the optometric industry were discussed.

\section{Demographics}

Fifty male $(66,7 \%)$ and 25 female (33,3\%) respondents took part in the research. Most of the respondents that took part in the study $47(63,7 \%)$ had been franchisees for two years and longer, and $28(37,3 \%)$ franchisees had been franchisees for less than two years. The majority of the respondents that took part in the research (45 or $60 \%)$ were married and $19(25,3 \%)$ were unmarried. Eight $(10,7 \%)$ of the respondents were divorced and only two $(2,7 \%)$ lived together.

All the respondents were in possession of a Senior Certificate and $64(44,1 \%)$ of them had obtained a university degree. Fifty-three $(70,7 \%)$ of the respondents were the owners of the franchise, and 22 $(29,3 \%)$ acted as managers of the franchise. The main group of the respondents $31(41,3 \%)$ were based in Gauteng, followed by 15 (20,0\%) from KwaZulu-Natal.

\section{Level of satisfaction with the elements of the franchisee-franchisor relationship}

In Table 2 the levels of agreement and disagreement between independent variables (franchisors less than two years as franchisors and those that have been franchisors for two years and longer) and the dependent variable, the elements of the franchise relationship (V1, V2, V3, V4, V5, V6, V7, V8, V9, V10, V11, V12 and V13) were analysed. The mean statistics and the significant difference results that were obtained from the independent t-tests were used to analyse Hypothesis 1, and then to either reject or not reject the hypothesis.

Table 2: Franchisees' levels of satisfaction with the elements of the franchise relationship

\begin{tabular}{|c|c|c|c|c|}
\hline \multicolumn{2}{|r|}{ Variables } & \multirow{2}{*}{$\begin{array}{c}\text { Mean / } \\
\text { (Standard Deviation) } \\
\text { Franchisees operating } \\
\text { for two years and less as } \\
\text { franchisees } \\
2,82 \\
(, 844)\end{array}$} & \multirow{2}{*}{$\begin{array}{c}\text { Mean / } \\
\text { (Standard Deviation) } \\
\text { Franchisees operating for } \\
\text { two years and longer as } \\
\text { franchisees } \\
2,62 \\
(, 881)\end{array}$} & \multirow{2}{*}{$\begin{array}{c}\text { P. Value } \\
\left(\mathrm{Ho}_{1}:\right. \\
\text { accepted if }>0.05 ; \\
\text { Rejected if }<0.05) \\
\text {,402 } \\
\mathrm{Ho}_{1} \text { accepted }\end{array}$} \\
\hline V1 & $\begin{array}{l}\text { I am satisfied with the profit } \\
\text { margins on products as } \\
\text { provided by the franchisor }\end{array}$ & & & \\
\hline V2 & $\begin{array}{l}\text { I am satisfied with the } \\
\text { franchisor's current } \\
\text { promotional activities }\end{array}$ & $\begin{array}{c}2,93 \\
(-1,614)\end{array}$ & $\begin{array}{c}3,21 \\
(-1,588)\end{array}$ & $\begin{array}{c}, 111 \\
\text { Ho }_{1} \text { accepted }\end{array}$ \\
\hline V3 & $\begin{array}{l}\text { I am satisfied with the support } \\
\text { received from the franchisor in } \\
\text { the selection process of a } \\
\text { distribution point }\end{array}$ & $\begin{array}{l}3.04 \\
(, 069)\end{array}$ & $\begin{array}{c}3.02 \\
(, 068)\end{array}$ & $\begin{array}{c}\text {,945 } \\
\text { Ho }_{1} \text { accepted }\end{array}$ \\
\hline
\end{tabular}




\begin{tabular}{|c|c|c|c|c|}
\hline V4 & $\begin{array}{l}\text { The franchisor specifies } \\
\text { specific geographical } \\
\text { areas for allocation per } \\
\text { franchisee }\end{array}$ & $\begin{array}{c}3,82 \\
(, 549)\end{array}$ & $\begin{array}{c}3,74 \\
(, 624)\end{array}$ & $\begin{array}{c}, 585 \\
\mathrm{Ho}_{1} \text { accepted }\end{array}$ \\
\hline V5 & $\begin{array}{l}\text { The franchisor } \\
\text { understands the training } \\
\text { needs of franchisees }\end{array}$ & $\begin{array}{c}3,18 \\
(, 043)\end{array}$ & $\begin{array}{c}3,17 \\
(, 043)\end{array}$ & $\begin{array}{c}, 966 \\
\text { Ho }_{1} \text { accepted }\end{array}$ \\
\hline V6 & $\begin{array}{l}\text { The franchisor provides } \\
\text { operational support by } \\
\text { means of an operational } \\
\text { manual }\end{array}$ & $\begin{array}{c}3,61 \\
(-, 909)\end{array}$ & $\begin{array}{c}3,77 \\
(-962)\end{array}$ & $\begin{array}{c}\text {,366 } \\
\text { Ho }_{1} \text { accepted }\end{array}$ \\
\hline V7 & $\begin{array}{l}\text { I operate } 100 \% \text { in } \\
\text { accordance with the } \\
\text { processes as prescribed } \\
\text { in the franchisor's } \\
\text { operational manual }\end{array}$ & $\begin{array}{l}3,11 \\
(, 725)\end{array}$ & $\begin{array}{c}2,96 \\
(, 736)\end{array}$ & $\begin{array}{c}, 471 \\
\text { Ho }_{1} \text { accepted }\end{array}$ \\
\hline V8 & $\begin{array}{l}\text { I am satisfied with the } \\
\text { financial support } \\
\text { provided by the } \\
\text { franchisor }\end{array}$ & $\begin{array}{c}3,71 \\
(, 555)\end{array}$ & $\begin{array}{c}3,57 \\
(, 564)\end{array}$ & $\begin{array}{c}, 580 \\
\mathrm{Ho}_{1} \text { accepted }\end{array}$ \\
\hline V9 & $\begin{array}{l}\text { I am satisfied with the } \\
\text { product and market } \\
\text { information as provided } \\
\text { by the franchisor }\end{array}$ & $\begin{array}{c}2,32 \\
(, 176)\end{array}$ & $\begin{array}{c}2,55 \\
(, 268)\end{array}$ & $\begin{array}{c}\text {,243 } \\
\text { Ho }_{1} \text { accepted }\end{array}$ \\
\hline V10 & $\begin{array}{l}\text { I am satisfied with the } \\
\text { franchisor's expectations } \\
\text { with regard to record } \\
\text { and bookkeeping } \\
\text { requirements }\end{array}$ & $\begin{array}{l}3,75 \\
(, 178)\end{array}$ & $\begin{array}{c}3,72 \\
(, 176)\end{array}$ & $\begin{array}{c}, 859 \\
\text { Ho }_{1} \text { accepted }\end{array}$ \\
\hline V11 & $\begin{array}{l}\text { I am satisfied with the } \\
\text { rate of development of } \\
\text { new products by the } \\
\text { franchisor }\end{array}$ & $\begin{array}{c}2,18 \\
(, 600)\end{array}$ & $\begin{array}{c}2,70 \\
(, 753)\end{array}$ & $\begin{array}{c}, 011 \\
\mathrm{Ho}_{1} \text { accepted }\end{array}$ \\
\hline V12 & $\begin{array}{l}\text { All distribution points of } \\
\text { the franchisor are of the } \\
\text { same standard with } \\
\text { regard to design and } \\
\text { layout }\end{array}$ & $\begin{array}{c}3,21 \\
(, 286)\end{array}$ & $\begin{array}{c}3,15 \\
(, 296)\end{array}$ & $\begin{array}{c}, 775 \\
\text { Ho }_{1} \text { accepted }\end{array}$ \\
\hline V13 & $\begin{array}{l}\text { I am satisfied with the } \\
\text { financial potential of the } \\
\text { geographical area } \\
\text { allocated to my franchise }\end{array}$ & $\begin{array}{c}3,43 \\
(2,490)\end{array}$ & $\begin{array}{c}2,91 \\
(2,635)\end{array}$ & $\begin{array}{c}, 015 \\
\text { Ho }_{1} \text { accepted }\end{array}$ \\
\hline
\end{tabular}

From Table 2 it is evident that there exists no significant difference between franchisees operating for two years and less as franchisees and franchisees operating for two years and longer as franchisees regarding their level of satisfaction with the elements of the franchise relationship between franchisees and franchisor.

A summary of Table 2 gives an overall picture of the level of satisfaction of franchisees operating for two years and less as franchisees and franchisees operating for two years and longer as franchisees with the elements of the franchise relationship between franchisors and franchisees. Franchisees operating for two years and less as franchisees and franchisees operating for two years and longer as franchisees indicated that:

- Franchisees are satisfied with the margins on products as provided by the franchisor.

- Franchisees are satisfied with the franchisor's current promotional activities.

- Franchisees are satisfied with the support received from the franchisor in the selection process of a distribution point. 
- The franchisor does specify specific geographical areas for allocation per franchisee.

- The franchisor does understand the training needs of franchisees.

- The franchisor provides operational support by means of an operational manual.

- Franchisees do not operate $100 \%$ in accordance with the processes as prescribed in the franchisor's operational manual.

- Franchisees are satisfied with the financial support provided by the franchisor.

- Franchisees are satisfied with the product and market information as provided by the franchisor.

- Franchisees are satisfied with the franchisor's expectations with regard to record and bookkeeping requirements.

- Franchisees are satisfied with the rate of development of new products by the franchisor.

- All distribution points of the franchisor are of the same standard with regard to design and layout.

- Franchisees are satisfied with the financial potential of the geographical areas allocated to their franchises.

A brief synopsis of the conclusion is that both groups of franchisees - franchisees operating as franchisees for two years and less and franchisees operating as franchisees for two years and longer - have high levels of satisfaction with the elements of the franchise relationship between franchisors and franchisees. $\mathbf{H o}_{1}$ is therefore accepted and $\mathbf{H a}_{\mathbf{1}}$ is rejected.

\section{CONCLUSIONS AND MANAGERIAL IMPLICATIONS}

The main aim of this article was to illustrate the level of franchisees' satisfaction with the franchise relationship. In order for franchisors to further increase the franchisees' levels of satisfaction with the franchise relationship, it is important to determine franchisees' needs with regard to the products, services, distribution, staff and processes as proposed or provided by the franchisor.

The results of the investigation hold important implications for future planning in the optometric industry in South Africa. Franchisors should take cognisance of the most important franchisee needs identified in this investigation. These needs were, in general, high profit margins on products, specified geographical areas, the existence and availability of a operational manual, fast rate of development of new products and high-quality promotional activities by the franchisor. With regard to specific outcomes, franchisors should be aware of the various gaps in meeting franchisees' needs, as mentioned under the recommendations.

In view of the outcomes of this research, it is concluded that the franchisees of the selected franchisor in the franchise industry displayed a high level of satisfaction with the franchise relationship between franchisors and franchisees.

\section{RECOMMENDATIONS}

Implementing the following recommendations derived from the research could assist in further increasing the levels of satisfaction with the franchise relationship between franchisors and franchisees and making the franchise industry in South Africa in general more marketing-orientated:

(1) The franchisor needs to develop internal communication programmes to support the already positive view held by franchisees with regard to profit margins and to indicate the contribution made by products and services as provided and prescribed by the franchisor.

(2) Training programmes provided by the franchisor should focus on the importance of franchisees adhering to the processes and procedures as prescribed in the operational manual provided and supported by the franchisor.

(3) The franchisor needs to use market research to measure the results of promotions. The franchisor needs to establish internal focus groups in order to involve franchisees more in decisions concerning promotional activities.

(4) It is important for the franchisor to do extensive research regarding the potential of selected geographical areas before allocating specific areas to franchisees. 
(5) The franchisor needs to develop more scientific methods to assist in the process of determining franchise fees. Methods should also be investigated for assisting franchisees who find themselves in financial difficulties.

This paper offers a new perspective on the generalisation that franchisees are not satisfied with the franchise relationship, and confirms a high level of satisfaction of franchisees with the franchise relationship between franchisees and franchisors. Franchisees are satisfied that the franchisor meets their needs with regard to products and services, prices and promotions, distribution and franchise fees as stipulated in the franchise agreement. The results indicate, contrary to popular belief, high levels of satisfaction with the franchise agreement and the elements of the relationship between franchisees and franchisors.

\section{REFERENCES}

ABATZOGLOU, J. 2002. A strategy for international expansion. Franchising Africa, June/July 2002:10-12.

BERGER, R. 2007. Franchise executives share insight on leadership. Franchise World, 39(1). [Online]. Available from: htt://ProQuest.com. [Accessed: 19/02/2007].

CALITZ, C.A. 2002. Franchise relationships. Franchising Africa Magazine Special Publication, April/May. 2002:5-7.

CHARNEY, C.C. 1996. Franchising in South Africa. MBA degree: University of South Africa.

FRANCHISE ASSOCIATION OF SOUTHERN AFRICA. 2000. Outline of Franchise. Internal document.

FRANCHISE DIGEST. 1999. Meeting the franchise challenge. Internal document.

FRAZER, L. 1998. Motivations for franchisors to use flat continuing fees, 15(6). [Online]. Available from: htt://docserver.emeraldinsight.com. [Accessed: 23/10/2006].

FRIEDMAN, A.M. 2006, Franchise success depends on communication, panellists say, Nation's Restaurant News, 40(440. [Online]. Available from: _htt://ProQuest.com. [Accessed: 24/02/2007].

GAY, L.R. \& DIEHL, P.L. 1992. Research methods for business and management. New York: Macmillan Publishing Company.

GORDON, B. 2002. Importance of disclosure documents. Start and Manage your Business, December 2001/January 2002, 6(1):34.

HOLMES, D. 2006. The Essence of Good Franchise Relations, Franchising World, 38(90. [Online]. Available from: htt://ProQuest.com. [Accessed: 24/02/2007].

ILLETSCHKO, K. 2005. How to franchise your business. $4^{\text {th }}$ edition. The Franchise Association of Southern Africa: Johannesburg.

KRIGE, L. 2001. The franchise lifecycle concept - a new paradigm in managing the franchisee/franchisor relationship. Masters in Marketing. University of Pretoria.

LUHN, R. 1994. Buying your first franchise. New York: Crisp Publications.

MALHOTRA, N.K. 1996. Marketing research: an applied orientation. $2^{\text {nd }}$ edition. Prentice Hall Inc.

MACQUEEN, B. 2006. Starting a Franchise. Business Day, June 25:3 
MCDANIEL, C. \& GATES, R. 2005. Marketing research. $6^{\text {th }}$ edition. Cincinnati: South-Western College.

MORGAN, R., HUNT, M.R \& NATHAN, S.G. 2003. A South African Lifestyle Concept. [Online]. Available from: http://www.frain.org.za. [Accessed: 28/07/2003].

NATHAN, G. 2006. The six stages of Franchise relationships. [Online]. Available from: www.Franchise-chat.com. [Accessed: 15/10/2006].

NELSON, S. 2006. Effectively Solving Disagreements With a Franchise System, Franchising World, Volume 38, number 9. [Online]. Available from:htt://ProQuest.com. [Accessed: 24/02/2007].

NIEMAN, G. 1998. The Franchise option, how to franchise your business. Eppindust: Juta.

OSSO. G. 2004. 2005 Franchise Directory. Franchise Association of Southern Africa: Johannesburg.

RAPHAËLE, M. \& RAFER, D. 1998. Training and power in franchise systems: the example of the UK automotive industry, 22(90. [Online]. Available from:htt://docserver.emeraldinsight.com. [Accessed: 23/10/2006].

PARKER, E. \& OSSO, G. 2000. Flying without wings. Johannesburg: Entrepreneurial Link.

PARKER, E. \& ILLERSCHKO, K. 2007. Franchising in South Africa. Northcliff, Johannesburg: Frontrunner.

SLATER, S.F. \& NAVER, J.C. 1994. Does competitive environment moderate the marketingorientation performance relationship?, Journal of Marketing, 58(460. [Online]. Available from: htt://docserver.emeraldinsight.com. [Accessed: 26/02/ 2007].

SPINELLI, S., ROSENBERG, R.M. \& BIRLEY, S. 2004. Franchising pathway to wealth creation. London: Prentice-Hall.

SHIVELL, K. \& BANNING, K. 1995. The franchise kit. New York: McGraw-Hill.

ST JACQUES, M. \& ST JACQUES, P. 2006. Cracking the code of franchise brand marketing: Cooperating for Success, Franchise World, 38(100. [Online]. Available from: htt://ProQuest.com. [Accessed: 24/02/2007].

SWART, N. 2002. Starting or buying your own business or a franchise. Cape Town: Juta.

SVENSSON G. 2004. Vulnerability in business relationships: the gap between dependence and trust. Journal of Business and Industrial Marketing, 19(70. [Online]. Available from: htt://docserver.emeraldinsight.com. [Accessed: 23/08/2007].

TERBLANCHE, E. \& SMIT, M. 1994. Entrepreneurial: the success formula. South African Jourbal for Entrepreneurship \& Small Business, November 1994:23-35.

UECKERMAN, H. 2003. Franchisebedryf floreer. Kleinsake Rapport, March 30:13.

UECKERMAN, H. 2006. Fasa aan voorpunt van sake. Kleinsake Rapport, March 26:2.

WEAVEN, S. \& FRAZER, L. 2006. Investment incentives for single and multiple unit franchisees, 9(3). [Online]. Available from:_htt://docserver. emeraldinsight.com. [Accessed: 23/10/2006]. 